Article

\title{
Betulin-3,28-diphosphate. Physico-Chemical Properties and In Vitro Biological Activity Experiments
}

\author{
Nina B. Melnikova ${ }^{1, *} \mathbb{1}$, Darina S. Malygina ${ }^{1}$, Irina N. Klabukova ${ }^{1}$, Denis V. Belov ${ }^{1}$, \\ Viktor A. Vasin ${ }^{2}$, Pavel S. Petrov ${ }^{2}$ (D), Alexander V. Knyazev ${ }^{3}$ and Alexey V. Markin ${ }^{3}$ \\ 1 Department of Pharmaceutical Chemistry, Privolzhsky Research Medical University, Minin sq., 10/1, \\ 603950 Nizhny Novgorod, Russia; mds73@yandex.ru (D.S.M.); klabukova.2054@mail.ru (I.N.K.); \\ belov.denbel2013@yandex.ru (D.V.B.) \\ 2 Department of Chemistry, N.P. Ogarev Mordovian State University, Bolshevistskaya St. 68, \\ 430005 Saransk, Russia; vasin@mrsu.ru (V.A.V.); petrovps@phys-chem.mrsu.ru (P.S.P.) \\ 3 Department of Chemistry, Lobachevsky University, 23/5 Gagarin Av., 603950 Nizhny Novgorod, Russia; \\ knyazevav@gmail.com (A.V.K.); markin@calorimetry-center.ru (A.V.M.) \\ * Correspondence: melnikovanb@gmail.com; Tel.: +7-902-309-2298
}

Received: 11 April 2018; Accepted: 11 May 2018; Published: 14 May 2018

\begin{abstract}
Betulin-3,28-diphosphate (BDP) obtained by phosphorylation of betulin using $\mathrm{POCl}_{3}$ has two main structural forms-BDP-1 and BDP-2-which differ in ethanol solubility, melting point, FTIR spectra, thermoanalytical characteristics and biological activity. Betulin-3,28-diphosphate and its sodium salt (Na-BDP) were characterized using ${ }^{13} \mathrm{C}$ and ${ }^{31} \mathrm{P}-\mathrm{NMR}$ spectra, powder XRD experiments, as well as differential scanning calorimetry (DSC) and thermogravimetric analysis (TG) methods. The exo-effects at $193 \pm 8{ }^{\circ} \mathrm{C}$ for ethanol soluble BDP- 1 samples $\left(-19.7 \pm 0.2 \mathrm{~kJ} \cdot \mathrm{mol}^{-1}\right)$ were about three times less than for ethanol insoluble BDP-2 samples $\mathrm{f}\left(-70.5 \pm 0.7 \mathrm{~kJ} \cdot \mathrm{mol}^{-1}\right)$. The DSC curves of Na-BDP-1 and Na-BDP-2 characterized the endo-effects having a maximum at $95-112{ }^{\circ} \mathrm{C}$. Water-soluble Na-BDP-1 was obtained as needle-like crystals, unlike poorly crystalline Na-BDP-2, whereas BDP-1 and BDP-2 aged with time and were isolated as amorphous substances. In vitro experiments on rats showed that compared to the control, Na-BDP-1 increased catalase and SOD activity and improved energy metabolism more effectively than Na-BDP-2.
\end{abstract}

Keywords: betulin-3,28-diphosphate and its sodium salt; thermoanalytical properties; antioxidant activity

\section{Introduction}

Lupane-type triterpenoids such as betulinic and betulonic acids, betulin succinates, betulin acetates and other esters of organic acids, show antitumor, lipid-lowering, hepatoprotective and antiviral properties [1-5]. The therapeutic use of betulin derivatives is limited to their poor solubility (from 1 to $100 \mu \mathrm{g} \cdot \mathrm{L}^{-1}$ ) and accordingly low bioavailability.

One of the ways to improve bioavailability of betulin derivatives as the potential active pharmaceutical ingredients is the synthesis of their derivatives containing sulfate, sulfonate, phosphate and phosphonate groups [6-8]. The derivatives of phosphoric acid have advantages, because their biotransformation easily proceeds under endogenous phosphatases, phosphorylases and kinases of blood and liver [9].

Betulin-3,28-diphosphate has proved to be a broad-spectrum drug in vitro and in vivo studies [8,10-12]. It was shown that betulin-3,28-diphosphate can be an antibacterial agent [10], an effective antiviral and antifungal agent $[8,11]$ as well as an inhibitor of complement system activation, which plays an important role in the treatment of many systemic diseases [12]. 
Although the biological activity of betulin-3,28-diphosphate is well-known, its physicochemical properties which determine solubility, spectral data, physicochemical constants, impurity profile of the compound have not been studied yet. Along with the existing advanced analytical methods for chemical characterization (i.e., fingerprinting) of potential medicines, the need for more rigorous evidence of their authenticity is growing.

Every medicine synthesis and its purification result in a characteristic imprint of a substance. In this context, different structural modifications contain important information on the synthesis history of substances. Considering that the information regarding the synthesis of these substances is often confidential, it is necessary to include a technique that will allow comprehensive chemical characterization of the substances.

Thermoanalytical methods (DSC/TG) are among the most important techniques to take physicochemical measurements and determine multiple structural forms and their phase transitions of a singular chemical entity [13-19]. It has been shown earlier that DSC can reliably characterize the observed phase transition with $<5 \mathrm{mg}$ of a tripeptide sample [20].

The information on DSC/TG characteristics can reveal a unique BDP pattern in the used synthesis and purification. The combination of thermoanalytical methods and other analyses has already been employed to study solid-state interactions of medicines with pharmaceutical excipients [21], but there are no available data in the literature on BDP analysis. Thermoanalytical methods were used to study betulin and betulinic acid polymorphism and solvatomorphism [19]. Solvates with ethanol and DMSO have not only different parameters of crystal lattices, different solubility, but also different pharmacological activity.

In this work we developed a synthesis of betulin-3,28-diphosphate $(3 \beta, 28$-diphosphatelup-20(29)-ene, BDP) and studied physicochemical properties and its sodium salt using potentiometry, DSC/TG, FTIR and powder XRD analysis. The final goal was to obtain BDP or its Na-BDP salt having good solubility and reproducible antioxidant activity results.

BDP was synthesized by a method similar to the one used to obtain steroid phosphates [22], using betulin and phosphorus oxytrichloride $\left(\mathrm{POCl}_{3}\right)$ in an organic solvent in the presence of triethylamine or pyridine as $\mathrm{HCl}$ acceptors (Scheme 1).

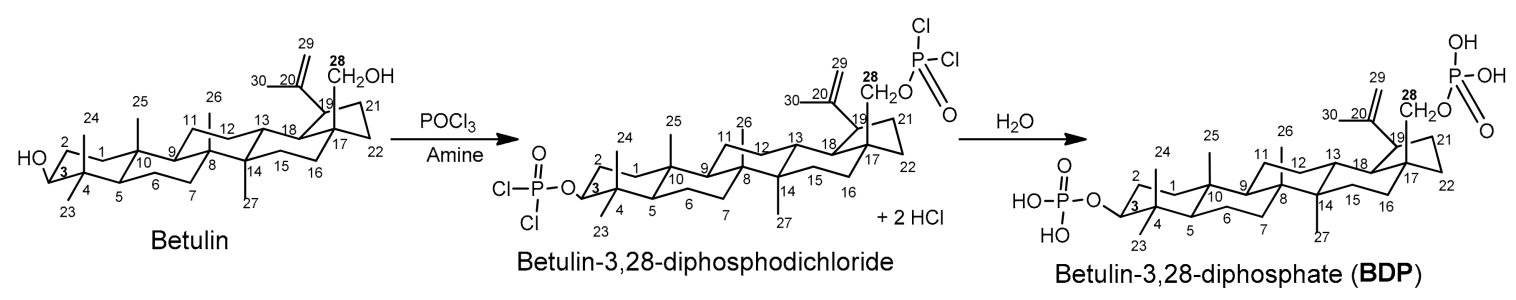

Scheme 1. Synthesis of betulin-3,28-diphosphate.

\section{Results and Discussion}

\subsection{Properties of the Betulin-3,28-diphosphate}

The solubility, melting point, and FTIR spectra of betulin-3,28-diphosphate (BDP) samples having the same chemical composition depended on the methods of its synthesis, purification and storage conditions. The first group of BDP samples (BDP-1) were readily soluble in ethanol (up to $10 \%$ ) and had a melting temperature equal to $147-148{ }^{\circ} \mathrm{C}(n=20)$. The second group of BDP samples (BDP-2) were limitedly soluble in ethanol (up to $1 \%$ ) with a melting temperature equal to $156-160{ }^{\circ} \mathrm{C}(n=15)$. The differences of BDP-2 sample properties were not due to the presence of monophoshorylated compounds, because the ${ }^{31} \mathrm{P}-\mathrm{NMR}$ spectra of BDP-2 samples were the same as the ${ }^{31} \mathrm{P}-\mathrm{NMR}$ spectra of BDP-1 samples and contained only the two signals that are characteristic for the C-O-P fragments at C-3 and C-28 for both BDP-1 and BDP-2 (Figures S1 and S2), and the integral ratios of these signals were 1:1 in all cases. The BDP structural forms in DMSO- $\mathrm{d}_{6}$ solution both in the presence and in 
absence of $\mathrm{H}_{3} \mathrm{PO}_{4}\left(\mathrm{Ph}_{3} \mathrm{P}\right.$ or $\mathrm{Met}_{3} \mathrm{P}$ standards) had similar ${ }^{31} \mathrm{P}-\mathrm{NMR}$ spectra (Figure S2). Control over hydrolysis products was exercised by adding $\mathrm{H}_{3} \mathrm{PO}_{4}$. Two phosphorus signals corresponding to diphosphate esters of betulin were observed, the integral ratio of signals being 1:1. Figure S2b shows the signal of a $\mathrm{Ph}_{3} \mathrm{P}$ standard $(\delta=-5.93 \mathrm{ppm})$. Figures $\mathrm{S} 1$ and $\mathrm{S} 2 \mathrm{~b}$ show the $\mathrm{H}_{3} \mathrm{PO}_{4}$ signal. Moreover, phosphorus content was the same for BDP-1 and BDP-2 samples after drying. Such different properties can be explained by the greater ability of the betulin derivatives dimers of BDP- 1 to include the solvent (ethanol, water, dioxane) in their structure [19].

The boiling water treatment, reprecipitation by acetone, which was not included in the betulin structure and the action of an aqueous solution of $\mathrm{HCl}$ on sodium salt of BDP were applied to remove the solvent molecules from the BDP dimers of the first group.

The FTIR spectra of BDP samples having different solubility and melting temperature differed in the "fingerprint" region, and also in the region corresponding to the stretching vibrations of phosphoryl-POH comb (2331, 2342, 1740-1650 cm $\mathrm{cm}^{-1}$ br. w.), P-O st, P=O st (1216-1196, 1100-940 $\mathrm{cm}^{-1}$ ), and hydroxyl groups-3400-3300 $\mathrm{cm}^{-1}$ (Figure 1a,b).

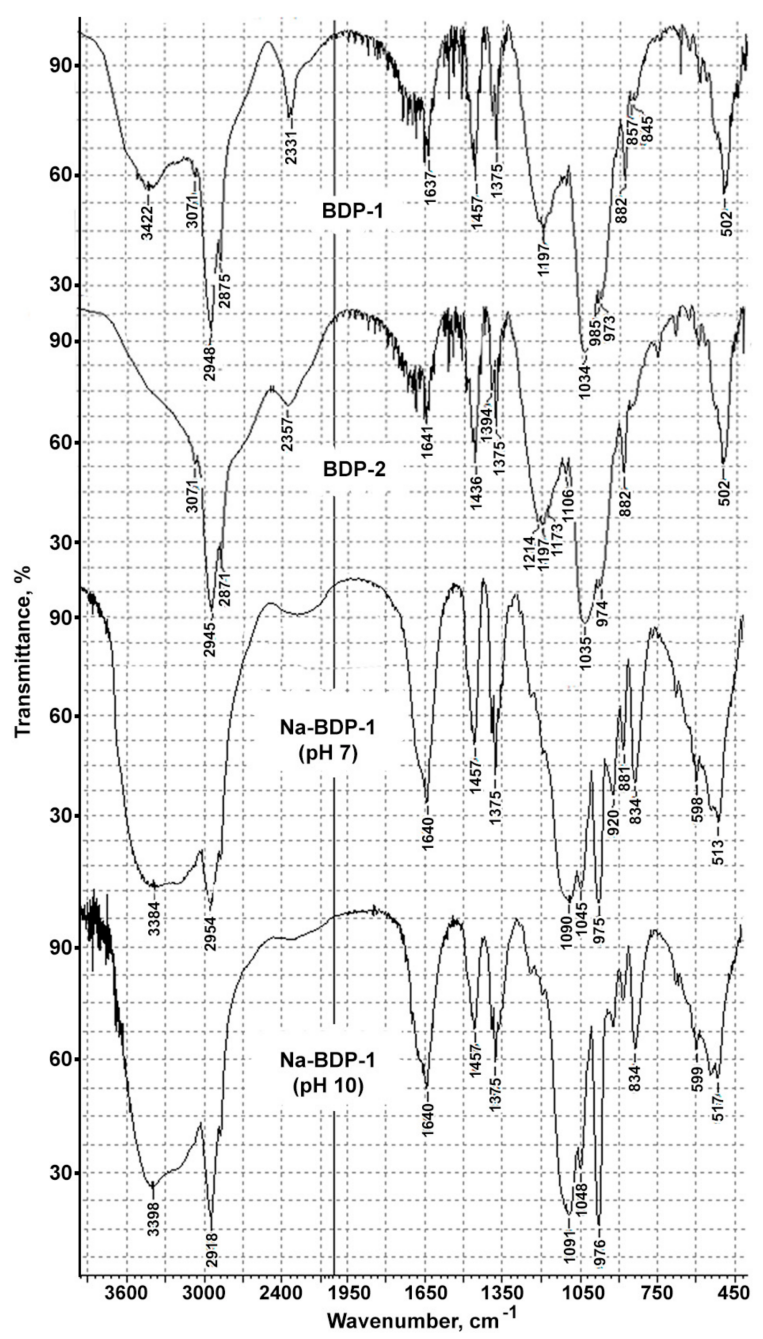

Figure 1. FTIR spectra BDP and Na-BDP: (a) Highly soluble in ethanol BDP-1; (b) BDP-2 sample obtained by acetone deposition from ethanol solution; (c) Na-BDP-1 formed at pH 7; (d) Na-BDP-1 formed at $\mathrm{pH}$ 10. FTIR was measured twice for 20 samples of each kind of BDP and Na-BDP.

Consequently, BDP samples having differences in FTIR spectra, melting temperature and solubility due to intermolecular interactions between the molecules of compounds or the molecules of the solvent and compound, may be considered as different structural forms of BDP [16]. 
The BDP forms had different thermoanalytical characteristics. The TG curve of highly soluble BDP-1 in ethanol had a stage characterizing the mass loss equal to $7 \%$ within the temperature range $72-150{ }^{\circ} \mathrm{C}$ (Figure 2a). The fact is likely to correspond to the removal of the solvent from the BDP samples. In contrast, the TG curve of the sample BDP-2 obtained by precipitating acetone from the ethanol solution did not have a stage in this temperature range indicating the absence of solvent molecules in the sample (Figure 2b).
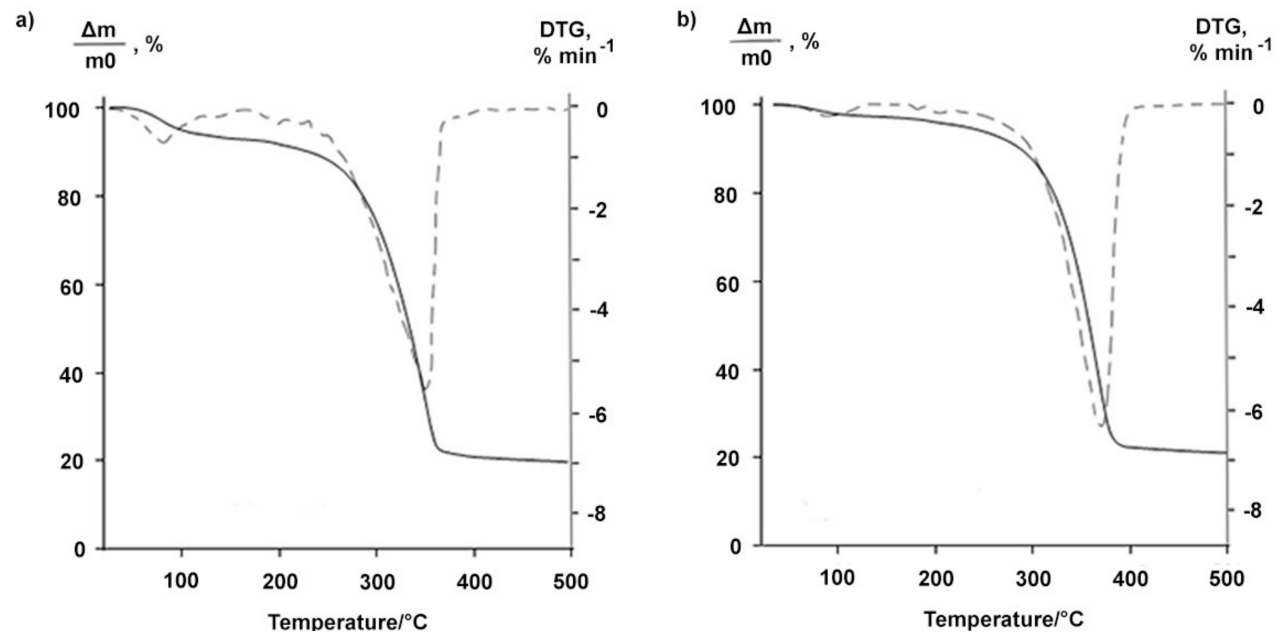

Figure 2. TG (solid line) and DTG (dashed line) curves of the BDP-1 (a) and BDP-2 (b).

The BDP samples were analyzed in more detail using differential scanning calorimetry (DSC). The DSC profile of BDP-1 shows two main peaks characterizing different exothermic processes. The first process proceeds within $151.2-155.9^{\circ} \mathrm{C}, \Delta \mathrm{H}_{1}=-15.5 \pm 0.2 \mathrm{~kJ} \cdot \mathrm{mol}^{-1}$; the second one is observed within $183.5-200.8^{\circ} \mathrm{C}, \Delta \mathrm{H}_{2}=-19.7 \pm 0.2 \mathrm{~kJ} \cdot \mathrm{mol}^{-1}$ (Figure 3a, Table 1). Moreover, a wide fuzzy peak (peak 1) appeared at $70-90{ }^{\circ} \mathrm{C}$ on the DSC curves (Figure 3a). This can be explained by either the removal of solvent molecules from the probable BDP inclusion complexes or by glass transition in the BDP samples.

The exo-effects of BDP-2 reprecipitated by acetone from BDP ethanol solution are observed within $161.3-172.8^{\circ} \mathrm{C}, \Delta \mathrm{H}_{1}=-23.5 \pm 0.2 \mathrm{~kJ} \cdot \mathrm{mol}^{-1}$; and $185.9-197.3^{\circ} \mathrm{C}, \Delta \mathrm{H}_{2}=-70.5 \pm 0.7 \mathrm{~kJ} \cdot \mathrm{mol}^{-1}$ (Figure 3b, Table 1).
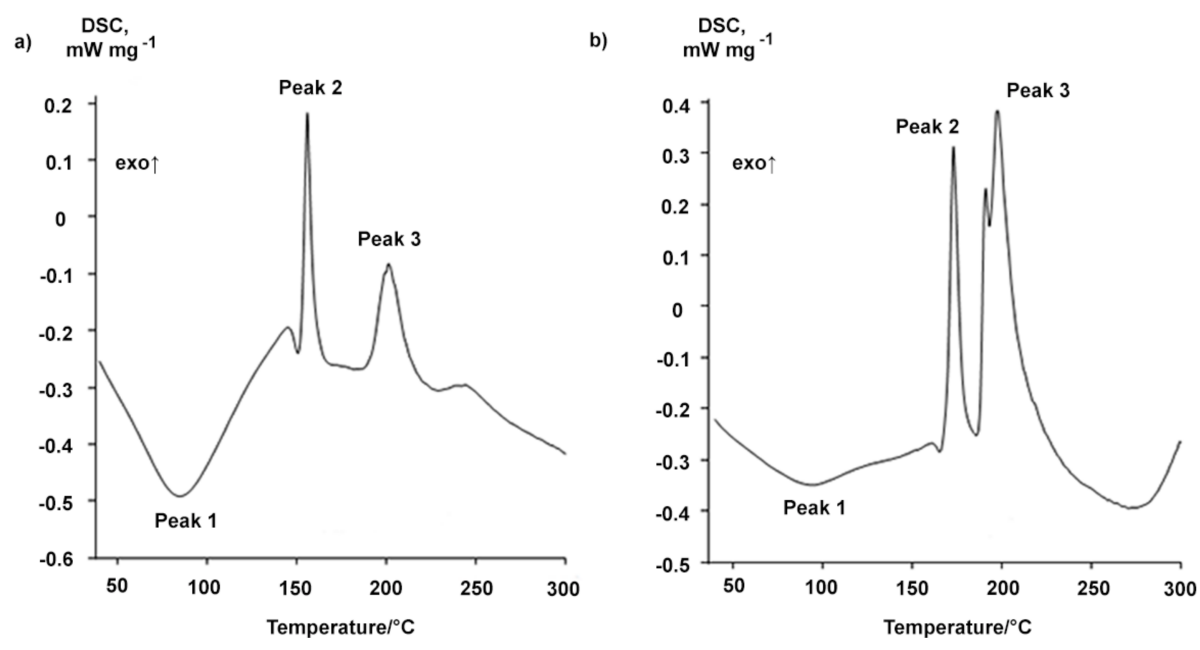

Figure 3. DSC-curves of the BDP-1 (a) and BDP-2 (b). 
Table 1. Thermophysical characteristics of the samples of betulin-3,28-diphosphate ${ }^{1}$.

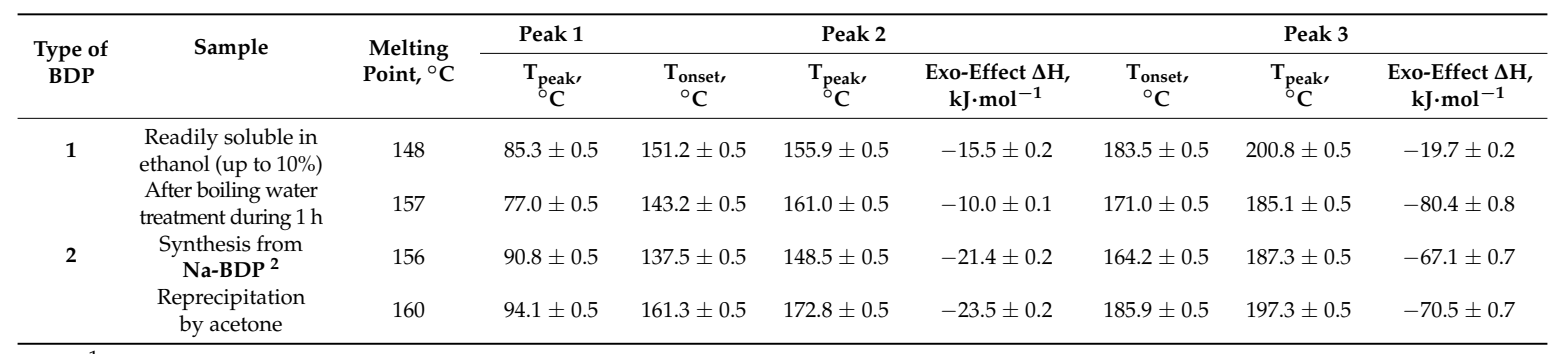
${ }^{1}$ Standard uncertainty of temperature $\mathrm{u}(T)=0.5^{\circ} \mathrm{C}$. Combined expanded uncertainty for the enthalpies of transitions $\mathrm{U}_{c, \mathrm{r}}\left(\Delta H^{0}{ }_{t r}\right)$ is 0.01 . The number of experiments repeated was $4 .{ }^{2} \mathrm{BDP}$ was obtained from BDP sodium salt by the action of an aqueous solution of $0.1 \mathrm{M}$ aqueous $\mathrm{HCl}$.

In general, for all BDP samples, the maximum of the first peak on DSC curves of the exo-effect varied within $150 \pm 13^{\circ} \mathrm{C}$, and the second peak maximum varied within $193 \pm 8^{\circ} \mathrm{C}$ (Table 1). The enthalpy $\Delta \mathrm{H}$ of the first exo-effect (peak 2) for all samples varied from -10.0 to $-23.5 \mathrm{~kJ} \cdot \mathrm{mol}^{-1}$, and the $\Delta \mathrm{H}$ value of the second exo-effect (peak 3) strongly depended on the structural type. The $\Delta \mathrm{H}$ value equaled to $-19.7 \pm 0.2 \mathrm{~kJ} \cdot \mathrm{mol}^{-1}$ for BDP-1, and the $\Delta \mathrm{H}$ exo-effect of BDP-2 varied from -67.1 to $-80.4 \mathrm{~kJ} \cdot \mathrm{mol}^{-1}$ (Table 1 ).

These findings enable to use the value of the enthalpy of the second exo-effect as well as the solubility and melting temperature, as a distinctive feature of BDP structural forms. It is probable that two or three-fold increase in the enthalpy of the second exo-effect for different BDP samples due to topochemical processes in solid state.

Besides, topochemical process may be the transition of the labile $\alpha$-epimer at C3-atom of BDP to the $\beta$-epimer in their mixture. These epimers transitions can be studied using NMR spectroscopy, since the $\alpha$ - and $\beta$-epimers of betulin derivatives, e.g., betulinic acid, display differences in their spectra, but the differences are insignificant. Two BDP C3-atom signals having a difference equal to $0.06 \mathrm{ppm}(6.25 \mathrm{~Hz})$ are observed in the ${ }^{13} \mathrm{C}-\mathrm{NMR}$ and ${ }^{13} \mathrm{C}$-DEPT spectra of BDP-1, while such splitting is absent in the spectra of BDP-2 (Figure 4).

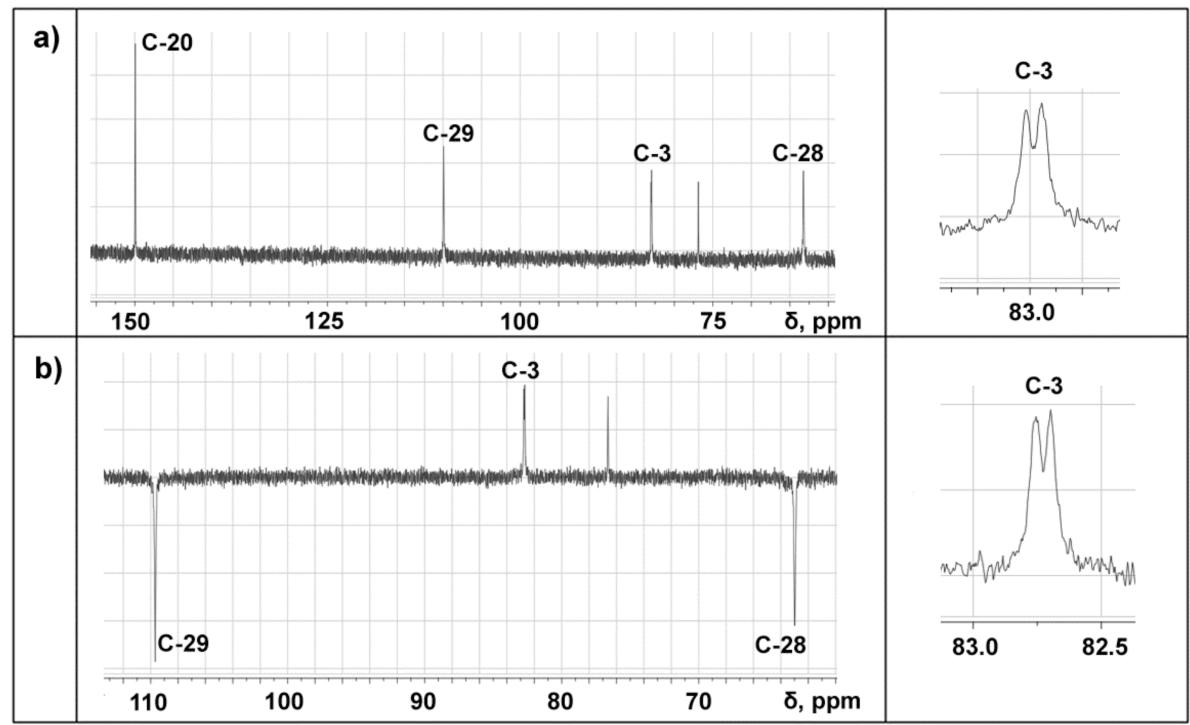

Figure 4. ${ }^{13} \mathrm{C}-\mathrm{NMR}$ spectrum (a) and dept spectrum (b) of BDP-1 (DMSO-d 6 , TMS standard).

The existence of $\alpha$ - and $\beta$-epimers of BDP was suggested by the ${ }^{1} \mathrm{H}$-NMR spectra too (Figure 5 and Figure S3). The two epimers had ${ }^{1} \mathrm{H}-\mathrm{NMR}$ resonance differences of $\mathrm{H}-3: \delta=2.97 \mathrm{ppm}$ for $\alpha-\mathrm{H}-3$ (wide triplet, $J=7.7 \mathrm{~Hz}$ ) versus $\delta=3.69 \mathrm{ppm}$ for $\beta-\mathrm{H}-3\left(\mathrm{ddd}, J_{1}=4.6 \mathrm{~Hz}, J_{2}=7.8 \mathrm{~Hz}, J_{3}=11.2 \mathrm{~Hz}\right.$ ). Similar differences in ${ }^{1} \mathrm{H}-\mathrm{NMR}$ resonances of the $3-\mathrm{H}$ protons of betulin derivative epimers were 
shown earlier $[23,24]$. The ${ }^{1} \mathrm{H}-\mathrm{NMR}$ resonances of $\mathrm{H}-28$ were observed in the region $3.96 \mathrm{ppm}(\mathrm{H}-28$, $\left.\mathrm{dd}, J_{1}=9.7 \mathrm{~Hz}, J_{2}=4.5 \mathrm{~Hz}\right)$ and $3.52 \mathrm{ppm}\left(\mathrm{H}-28^{\prime}, \mathrm{dd}, J_{1}=9.5 \mathrm{~Hz}, J_{2}=4.5 \mathrm{~Hz}\right)$.

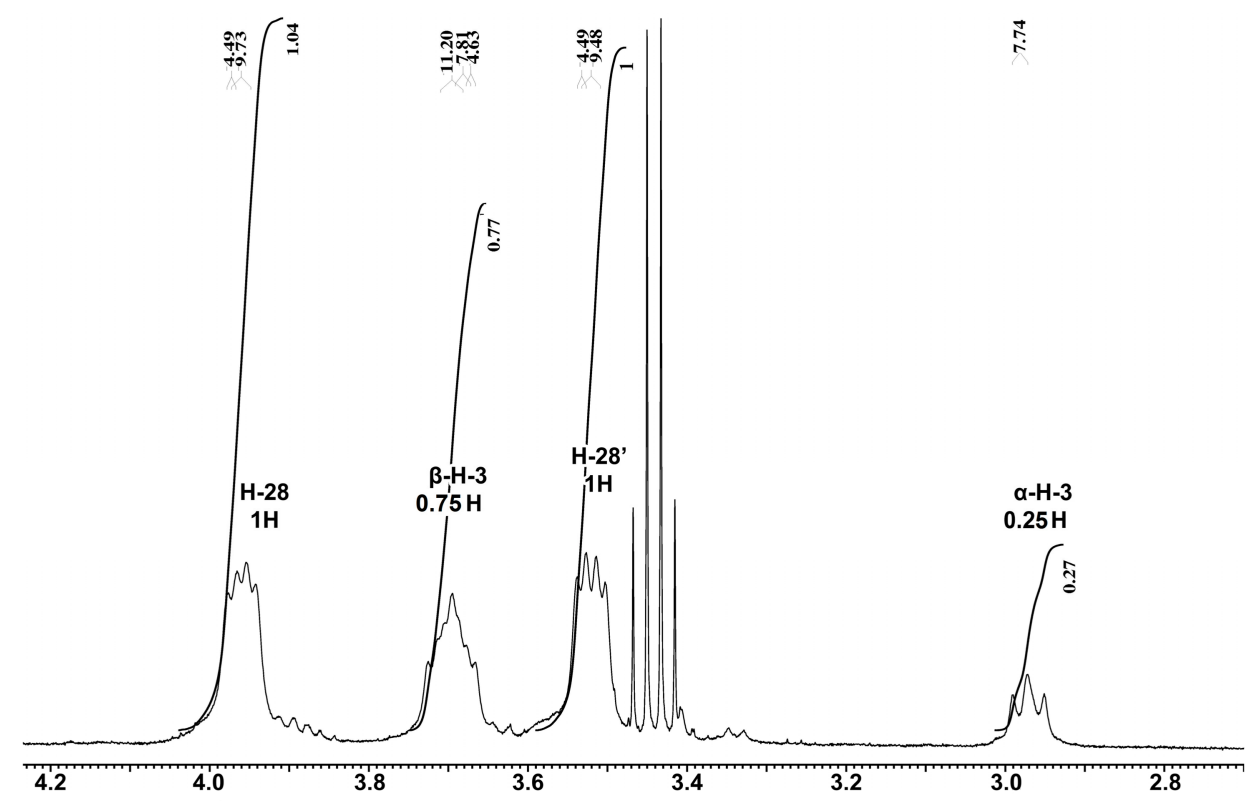

Figure 5. Fragment of the ${ }^{1} \mathrm{H}-\mathrm{NMR}$ spectrum of BDP-1 stored during one month (DMSO- $\mathrm{d}_{6}$, TMS standard, $400 \mathrm{MHz})$. Note: $\delta 0.68-1.99 \mathrm{ppm}\left(42 \mathrm{H}, \mathrm{m}, 6 \mathrm{CH}_{3},\left(\mathrm{CH}_{2}\right)_{10},(\mathrm{CH})_{4}\right), 2.35-2.42 \mathrm{ppm}(1 \mathrm{H}, \mathrm{m}$, $\mathrm{H}-19), 2.97 \mathrm{ppm}(0.25 \mathrm{H}$, wide $\mathrm{t}, \alpha-\mathrm{H}-3, J=7.7 \mathrm{~Hz}), 3.69 \mathrm{ppm}(0.75 \mathrm{H}$, ddd, $\beta-\mathrm{H}-3 \mathrm{~m} J=4.6,7.8,11.2 \mathrm{~Hz})$, $3.96 \mathrm{ppm}(1 \mathrm{H}, \mathrm{dd}, \mathrm{H}-28, J=9.7,4.5 \mathrm{~Hz})$ and $3.52 \mathrm{ppm}\left(\mathrm{H}, \mathrm{dd}, \mathrm{H}-28^{\prime}, J=9.5,4.5 \mathrm{~Hz}\right), 4.55,4.69 \mathrm{ppm}(2 \mathrm{H}$, two s, H-29), 5.69 (protons in the phosphate groups $\mathrm{O}-\mathrm{P}(\mathrm{O})(\mathrm{OH})_{2}$, wide blurred s).

Readily ethanol soluble BDP-1 was exposed to aging with time and a loss of solubility resulted from BDP-1 structure changes. The BDP-1 samples were thus transformed into BDP-2 with concomitant alcohol solubility loss when the BDP-1 samples were dried at $150 \pm 10^{\circ} \mathrm{C}$ for $3 \mathrm{~h}$ or at room temperature for 3 months, whereas BDP-2 samples were more stable and their properties changed insignificantly.

Considering that the topochemical processes, including "cold crystallization", epimerization and polymorph transition, processes in solid state of BDP proceed more slowly than in solutions and the epimerization of BDP in the solutions proceeds more easily. The ratio of $\alpha$ - and $\beta$-epimers may differ over time. Figure 5 shows the ${ }^{1} \mathrm{H}-\mathrm{NMR}$ spectrum of a BDP-1 sample stored during one month, where the integral ratio of $\alpha-\mathrm{H}-3$ and $\beta-\mathrm{H}-3$ signals equals 1:3.

It may be proposed that the transition of the $\alpha$-epimer to the $\beta$-epimer contributes to the change in the solubility and thermoanalytical characteristics of the structural modifications of the BDP. The effect of different structural forms of BDP on the biological activity may be corrected by forming a water-soluble sodium salt.

\subsection{Water-Soluble Sodium Salt of Betulin-3,28-diphosphate}

The sodium salt of BDP was obtained by adding an aqueous alkaline solution to an ethanol BDP solution. Potentiometric titration of an ethanol solution of BDP-1 by $0.2-4.0 \mathrm{M}$ alkali solutions showed the interaction of $\mathrm{BDP}$ and $\mathrm{NaOH}$ to proceed in two stages, the stoichiometry of titration being 1:2 and 1:4. Figure 6 shows a typical titration curve $\mathrm{pH}=\mathrm{f}(\mathrm{V})$ for BDP- 1 by aqueous $0.2 \mathrm{M} \mathrm{NaOH}$ and its differential form $\Delta \mathrm{pH} / \Delta \mathrm{V}=\mathrm{f}(\mathrm{V})$. 

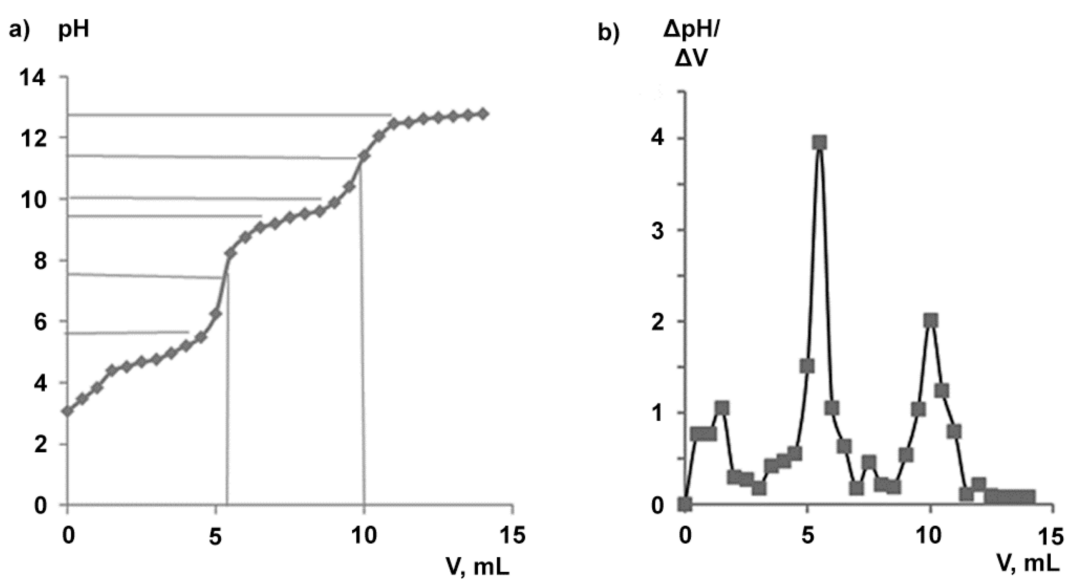

Figure 6. Potentiometric titration of $\mathrm{BDP}$ by $0.2 \mathrm{M} \mathrm{NaOH}$ aqueous solution: (a) $\mathrm{pH}=\mathrm{f}(\mathrm{V})$; (b) differential curve $\Delta \mathrm{pH} / \Delta \mathrm{V}=\mathrm{f}(\mathrm{V}), n=8$.

FTIR-spectral data (Figure 1c,d) and ${ }^{31}$ P-NMR spectra (Figure S4) supported the formation of sodium salts of BDP which were precipitated by acetone from aqueous-ethanol solutions at $\mathrm{pH} 7$ and at $\mathrm{pH}$ 10. Na-BDP deposited at $\mathrm{pH} 10$ is a crystalline hydrate Na-BDP $\times 8 \mathrm{H}_{2} \mathrm{O}$.

Water-soluble Na-BDP-1 was obtained as needle-like crystals, unlike the poorly crystalline Na-BDP-2, whereas BDP-1 and BDP-2 aged with time and were isolated as an amorphous substance in accordance with powder XRD data (Figure 7). It should be noted that amorphous samples have a bimodal molecular weight distribution, as evidenced by the complex form of the peak at small angles.

a)
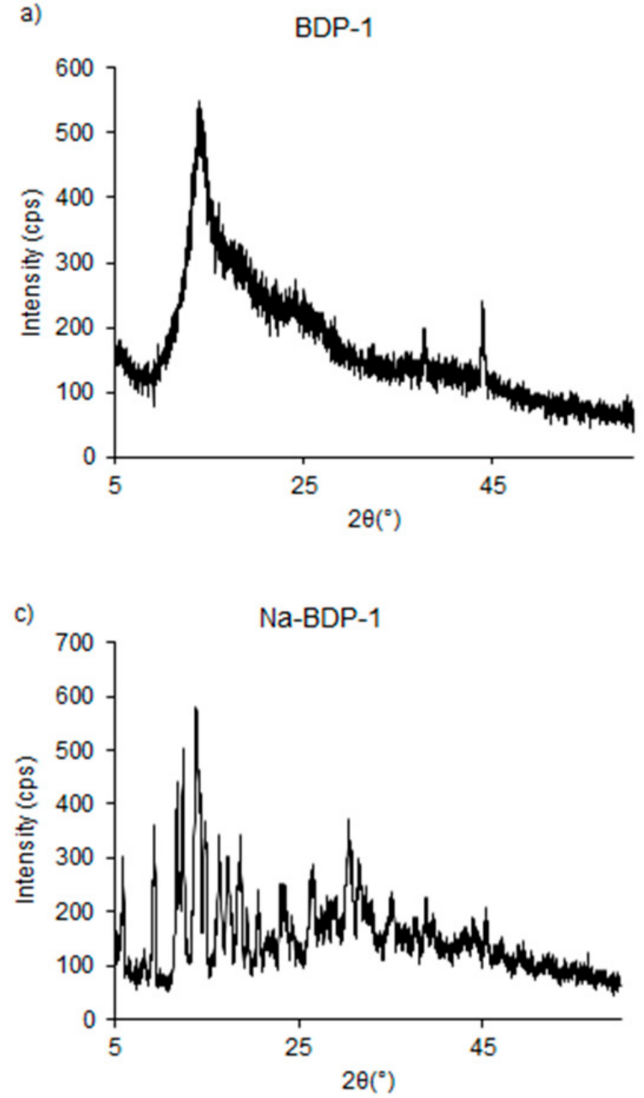

b)
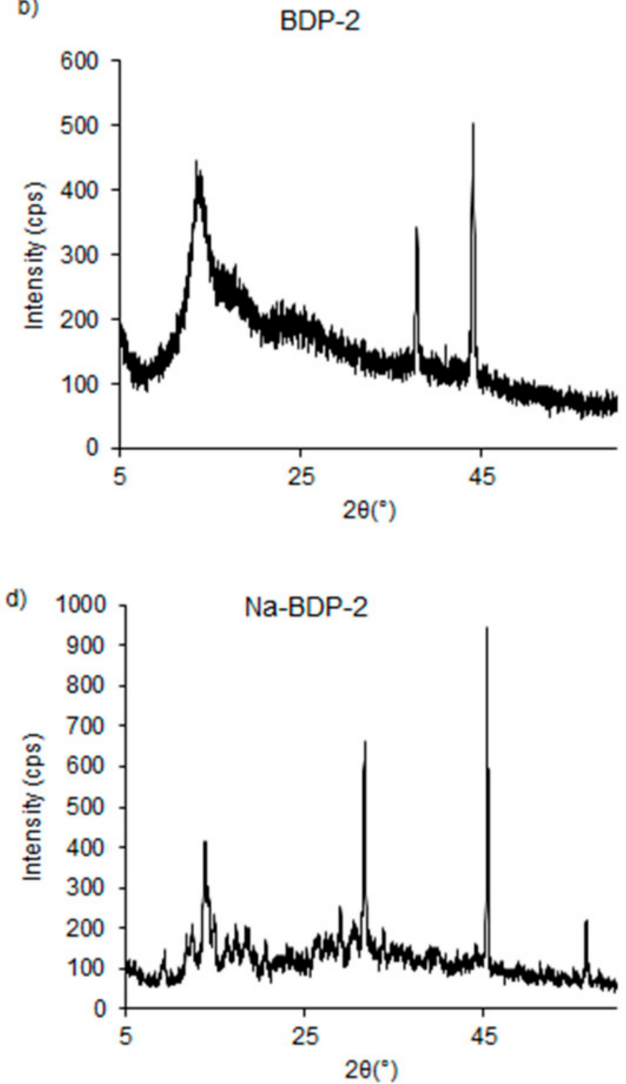

Figure 7. Powder XRD data of the samples BDP-1 (a), BDP-2 (b), Na-BDP-1 (c) and Na-BDP-2 (d). 
The DSC curves of Na-BDP characterize the endo-effect with a maximum at $95-112{ }^{\circ} \mathrm{C}$ (Figure 8), probably due to the removal of bound water molecules in Na-BDP hydrates. One can see two stages on the TG curve of the BDP sodium salt (Figure 9), the first stage corresponding to a water loss equal to $16.4 \%$, that is about 7.5 water molecules per the Na-BDP molecule. The effect can be associated with the removal of not only crystallization water from the hydrate structure, but also the occluded water in the crystal lattice or between the solid grains. The process of water loss in Na-BDP crystalline hydrate leads to the loss of its solubility in water during storage.
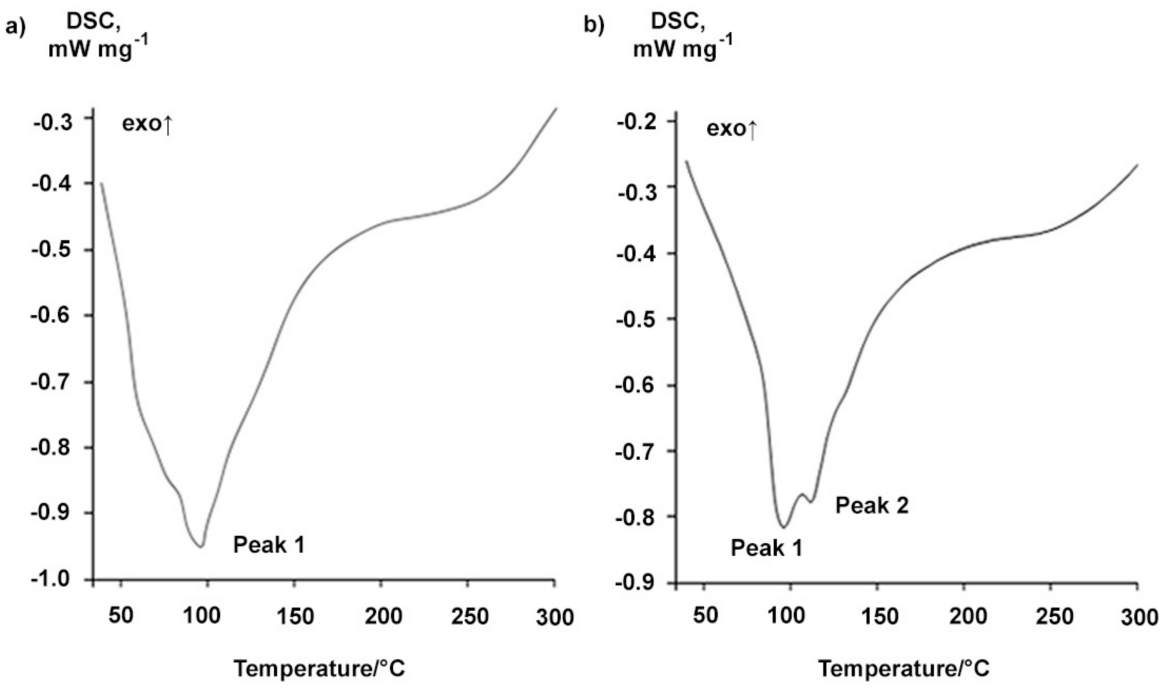

Figure 8. DSC-curves of sodium salt of betulin-3,28-diphosphate: (a) Na-BDP-1; (b) Na-BDP-2. The number of the experiments repeated was 4 .
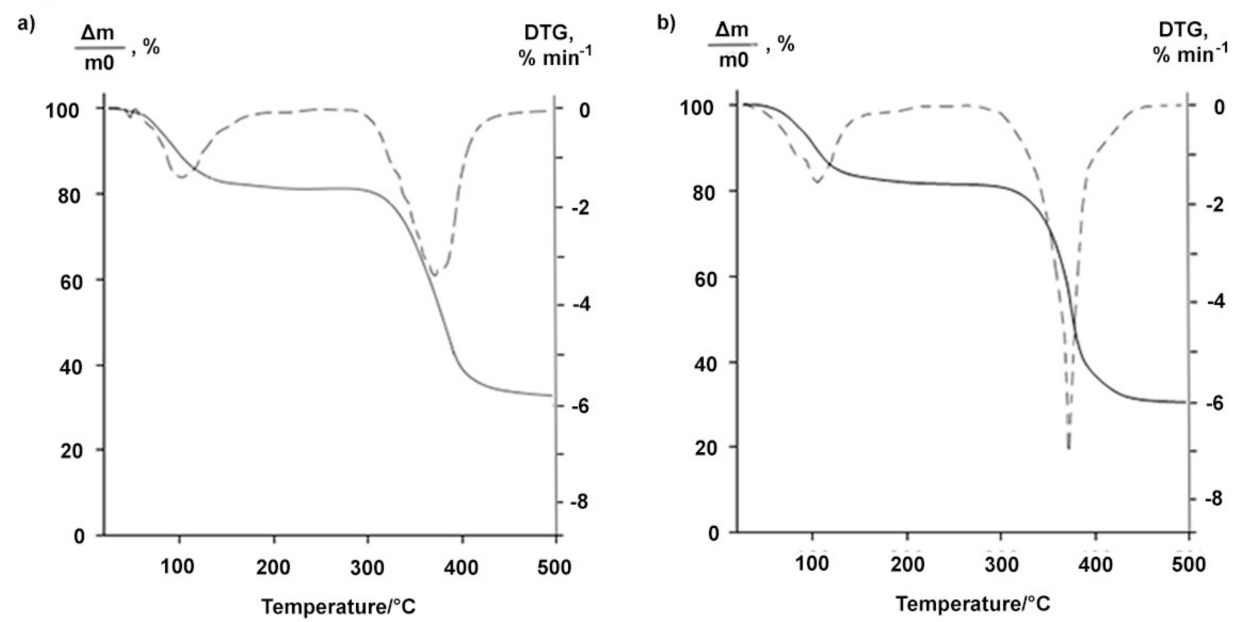

Figure 9. TG (solid line) and DTG (dashed line) curves of betulin-3,28-diphosphate: (a) Na-BDP-1; (b) Na-BDP-2. The number of the experiments repeated was 4.

\subsection{Biological Activity of Betulin-3,28-diphosphate In Vitro Experiments}

We investigated the biological activity of the highly ethanol soluble BDP-1 as its water-soluble sodium salt-Na-BDP. Biochemical indexes, such as antioxidant enzyme activity of catalase and superoxide dismutase SOD, total antioxidant status TAS, lipoperoxidation LPO and malonic dialdehyde MDA level in plasma and erythrocytes in rat blood were evaluated compared to the control. The effect of BDP on energy metabolism was assessed by increasing of the lactate dehydrogenase LDH level in direct and reverse reactions. In addition, the effect on biological activity of poorly soluble 
in ethanol BDP-2 was studied. In the experiments, a mixture of the BDP forms (BDP-1:BDP-2 = 2:1) was used as the salt complex of BDP with meglumine at the molar ratio 1:4. Table 2 shows the high antioxidant enzymatic activity of BDP, while the effect of BDP-1 exceeds almost twice the activity of the BDP samples mixture. Taking into account the ratio of BDP-1 and BDP-2 in the mixture is 2:1, we can conclude a weak effect of BDP-2 on the enzyme activity. The non-enzymatic activity (LPO decrease) of BDP-1 was also better in comparison with the mixture of BDP-1 and BDP-2 (Table 2).

Table 2. Biochemical parameters of rat blood under the influence of BDP aqueous solutions in the dose $2 \mu \mathrm{g} \cdot \mathrm{mL}^{-11}$.

\begin{tabular}{ccc}
\hline \multirow{2}{*}{ Parameters } & \multicolumn{2}{c}{ \% of Control } \\
\cline { 2 - 3 } & BDP-1 as Sodium Salt & Mixture of BDP-1 and BDP-2 (2:1) \\
\hline Catalase & $299.0 \pm 13.6$ & $170.5 \pm 3.5$ \\
SOD & $334.9 \pm 2.0$ & $165.2 \pm 2.5$ \\
MDA $_{\text {plasma }}$ & $98.9 \pm 13.0$ & $115.07 \pm 0.2$ \\
MDA $_{\text {erythrocyte }}$ & $57.0 \pm 8.0$ & $83.1 \pm 3.7$ \\
$\mathrm{LDH}_{\text {direct }}$ & $423.6 \pm 7.0$ & $271.2 \pm 6.5$ \\
$\mathrm{LDH}_{\text {reverse }}$ & $236.6 \pm 4.0$ & $110.0 \pm 3.0$ \\
$\mathrm{LPO}_{\text {plasma }}$ & $92.8 \pm 0.9$ & $101.2 \pm 0.7$ \\
$\mathrm{LPO}_{\text {erythrocyte }}$ & $68.6 \pm 0.5$ & $96.8 \pm 1.4$ \\
TAS & $117.6 \pm 1.9$ & $102.7 \pm 4.0$ \\
\hline
\end{tabular}

${ }^{1}$ The number of the repeat experiments was three. ${ }^{2}$ A mixture of BDP-1 and BDP-2 was dissolved in water in the presence of meglumine.

Moreover, special attention should be given to a stronger BDP effect on BDP-1 energy metabolism in comparison with the mixture. The LDH activity was found to increase fourfold in the direct reaction and in twice the reverse reaction under the action of BDP-1.

\section{Materials and Methods}

\subsection{Materials}

Betulin was isolated from Betula pendula bark using the methods in [25]. Phosphorus oxytrichloride (Sigma Aldrich, Moscow, Russia), purified water (resistivity $\geq 18 \mathrm{M} \Omega \cdot \mathrm{cm}$, Millipore, Merck, Darmstadt, Germany).

\subsection{FTIR Analysis}

FTIR spectra in the $400-4000 \mathrm{~cm}^{-1}$ range were measured by an IR Prestige-21 FTIR spectrometer (Shimadzu, Kyoto, Japan) equipped with a KBr beam splitter. For performing these measurements, a pellet from well-dried $\mathrm{KBr}$ was prepared by a standard cold pressing method. Resolution was $0.5 \mathrm{~cm}^{-1}$. The number of scans was 45 .

\subsection{NMR Analysis}

${ }^{13} \mathrm{C}-,{ }^{1} \mathrm{H}-,{ }^{31} \mathrm{P}-\mathrm{NMR}$ spectra were recorded at 101, 400 and 202,46 $\mathrm{MHz}$, respectively, on a JNMECX400NMR-spectrometer (Jeol Ltd., Tokyo, Japan), using as solvents DMSO- $d_{6}, \mathrm{CDCl}_{3}$, or $\mathrm{D}_{2} \mathrm{O}$.

\subsection{Differential Scanning Calorimetry}

To investigate the thermal behavior and to measure the heat capacities of BDP under study within the temperature range from $t=20$ to $300{ }^{\circ} \mathrm{C}$, we used a DSC 204 F1 Phoenix differential scanning calorimeter with $\mu$-sensor (Netzsch-Gerätebau, Selb, Germany). The calorimeter was calibrated and tested against melting of standard calibration set (indium, bismuth, zinc, tin, biphenyl, mercury, cesium chloride, and potassium nitrate) [26]. It was established that the apparatus and 
the measurement procedure enabled to measure the temperature of phase transitions with the standard uncertainty $\mathrm{u}(T)=0.5^{\circ} \mathrm{C}$, and the enthalpies of transitions with the combined expanded uncertainty $\mathrm{U}_{\mathrm{c}, \mathrm{r}}\left(\Delta H^{\circ}{ }_{t r}\right)=0.01$. The temperatures and the enthalpies of phase transitions were evaluated according to the standard Netzsch Proteus Software (Selb, Germany) procedure. The heat capacity was determined by the ratio, sapphire being used as a standard reference sample. The technique to determine the temperatures and the enthalpies of transitions is described in detail $[27,28]$ and in Netzsch Proteus Software. The heating rate was $5{ }^{\circ} \mathrm{C} \mathrm{min}-1$; it being measured in argon atmosphere.

\subsection{Thermogravimetric Analysis}

The TG curves were recorded in the $20-500{ }^{\circ} \mathrm{C}$ range, on a TG $209 \mathrm{~F} 1$ Iris TG analyzer (Netzsch-Gerätebau) using open ceramic/aluminum sample pans (sample mass 4-16 mg), under dynamic argon atmosphere $\left(25 \mathrm{~mL} \cdot \mathrm{min}^{-1}\right)$ and heating rate of $5{ }^{\circ} \mathrm{C} \mathrm{min}^{-1}$.

\subsection{Powder X-ray Diffraction Analysis}

Powder X-ray diffraction patterns were obtained using Shimadzu X-ray diffractometer XRD-6000 at $295(2) \mathrm{K}$ with $\mathrm{Cu} \mathrm{K} \alpha$ radiation $(\lambda=1.5418 \AA)$, in the Bragg-Brentano reflection geometry. The samples were collected in the $2 \theta$ range between $5-50^{\circ}$ with steps of $0.026^{\circ}$ and $100 \mathrm{~s}$ of step size, using a scan speed $(\% / \mathrm{s})$ of 0.067335 . On the X-ray diffraction patterns of amorphous samples, there are diffraction peaks at $37.5^{\circ}$ and $44.0^{\circ}$ referring to the cuvette material.

\subsection{Synthetic Procedures}

\subsubsection{Synthesis of Betulin-3,28-diphosphate (BDP, 3ß,28-diphosphate-lup-20(29)-ene)}

Phosphorus oxytrichloride (7.56 mL, $81.6 \mathrm{mmol}$; Sigma Aldrich, Moscow, Russia, 99\%) in dioxane $(60 \mathrm{~mL})$ was added dropwise to a solution of betulin $(6.0 \mathrm{~g}, 13.56 \mathrm{mmol})$ in a mixture of dioxane $(120 \mathrm{~mL})$ and pyridine $(7.08 \mathrm{~mL}, 81.6 \mathrm{mmol})$ at $10-20^{\circ} \mathrm{C}$ into a three-necked flask. The reaction mixture was stirred for $24 \mathrm{~h}$ at room temperature and then treated by water and ice mixture $(1000 \mathrm{~g})$ in the beaker. White precipitate was filtered off and washed by water many times. A wet sediment contained $3-25 \%$ of water that corresponds to the hydrate of betulin-3,28-diphosphate $\times \mathrm{H}_{2} \mathrm{O}$, where $\mathrm{x}=1-9$ (7.90 g, $94 \%$ as dried product): mp: $147-148{ }^{\circ} \mathrm{C}$ (BDP-1), $156-160{ }^{\circ} \mathrm{C}$ (BDP-2); UV (EtOH): $\lambda_{\max }$ (log $\left.\varepsilon\right)$ 256 (2.64) nm; FTIR (KBr): $v_{\max } 3421,2331,2342,1641-1700,1240,1031,973,501 \mathrm{~cm}^{-1} ;{ }^{1} \mathrm{H}-\mathrm{NMR}$ (DMSO- $\left.d_{6}, 400 \mathrm{MHz}\right) \delta 0.68-1.99\left(42 \mathrm{H}, \mathrm{m}, 6 \mathrm{CH}_{3},\left(\mathrm{CH}_{2}\right)_{10},(\mathrm{CH})_{4}\right), 2.35-2.42(1 \mathrm{H}, \mathrm{m}, \mathrm{H}-19), 2.97(0.25 \mathrm{H}$, wide $\mathrm{t}, \alpha-\mathrm{H}-3, J=7.7 \mathrm{~Hz}), 3.69(0.75 \mathrm{H}$, ddd, $\beta-\mathrm{H}-3 \mathrm{~m}, J=4.6,7.8,11.2 \mathrm{~Hz}), 3.96(1 \mathrm{H}, \mathrm{dd}, \mathrm{H}-28, J=9.7$, $4.5 \mathrm{~Hz})$ and $3.52\left(\mathrm{H}, \mathrm{dd}, \mathrm{H}-28^{\prime}, J=9.5,4.5 \mathrm{~Hz}\right), 4.55,4.69(2 \mathrm{H}$, two s, H-29), 5.69 (protons in the phosphate groups $\mathrm{O}-\mathrm{P}(\mathrm{O})(\mathrm{OH})_{2}$, wide blurred s); ${ }^{13} \mathrm{C}-\mathrm{NMR}$ (DMSO- $\left.d_{6}, 101 \mathrm{MHz}\right) \delta 149.93(\mathrm{C}, \mathrm{C}-20)$, $109.92\left(\mathrm{CH}_{2}, \mathrm{C}-29\right), 82.96(\mathrm{CH},=\mathrm{CHOH}), 63.22\left(\mathrm{CH}_{2}, \mathrm{CH}_{2} \mathrm{OH}\right), 54.90(\mathrm{CH}, \mathrm{C}-5), 49.71(\mathrm{CH}, \mathrm{C}-9), 48.11$ (CH, C-19), 47.26 (CH, C-18), 46.75 (C, C-17), 42.30 (C, C-14), 40.48 (C, C-8), 38.57 (C, C-4), 38.35 ( $\mathrm{CH}_{2}$, C-1), 37.99 (C, C-10), $37.07(\mathrm{CH}, \mathrm{C}-13), 36.57\left(\mathrm{CH}_{2}, \mathrm{C}-7\right), 33.79\left(\mathrm{CH}_{2}, \mathrm{C}-22\right), 29.11\left(\mathrm{CH}_{2}, \mathrm{C}-21\right), 28.96$ $\left(\mathrm{CH}_{2}, \mathrm{C}-16\right), 28.17\left(\mathrm{CH}_{3}, \mathrm{C}-23\right), 27.90\left(\mathrm{CH}_{2}, \mathrm{C}-2\right), 26.57\left(\mathrm{CH}_{2}, \mathrm{C}-15\right), 24.83\left(\mathrm{CH}_{2}, \mathrm{C}-12\right), 20.43\left(\mathrm{CH}_{2}\right.$, $\mathrm{C}-11), 18.84\left(\mathrm{CH}_{3}, \mathrm{C}-30\right), 18.01\left(\mathrm{CH}_{2}, \mathrm{C}-6\right), 16.14\left(\mathrm{CH}_{3}, \mathrm{C}-26\right), 15.91\left(\mathrm{CH}_{3}, \mathrm{C}-24\right), 15.70\left(\mathrm{CH}_{3}, \mathrm{C}-25\right)$, $14.56\left(\mathrm{CH}_{3}, \mathrm{C}-27\right) ;{ }^{31} \mathrm{P}-\mathrm{NMR}$ (DMSO- $\left.d_{6}, 202.46 \mathrm{MHz}\right) \delta-0.4(\mathrm{~d}, J=8.2 \mathrm{~Hz}$, phosphoric acid residue at $\mathrm{C}-3 \beta), 0.48 \mathrm{ppm}(\mathrm{t}, J=4.6 \mathrm{~Hz}$, phosphoric acid residue at $\mathrm{C}-28)$.

In the ${ }^{13} \mathrm{C}-\mathrm{NMR}$ spectrum the signals of the C-28 and C-3 atoms of BDP (60 and $80 \mathrm{ppm}$, respectively) were shifted by 3 ppm in comparison with botulin, which is characteristic for phosphoric acid esters.

The ${ }^{31} \mathrm{P}-\mathrm{NMR}$ spectra of BDP in DMSO- $\mathrm{d}_{6}$ were obtained in the presence of $\mathrm{Ph}_{3} \mathrm{P}(\delta=-6.0 \mathrm{ppm})$ and $\mathrm{H}_{3} \mathrm{PO}_{4}(\delta=-0.14 \mathrm{ppm})$ which was added just before recording the spectrum at $30{ }^{\circ} \mathrm{C}$. The phosphoric acid residue at $\mathrm{C}-3 \beta$ of $\mathrm{BDP}$ in the spectrum without decoupling of the protons was recorded as a doublet $\left(\delta=-0.4 \mathrm{ppm}\right.$ ), while the coupling constant $\mathrm{J}_{\mathrm{H}-\mathrm{P}} \sim 8 \mathrm{~Hz}$ is typical for $\mathrm{CH}-\mathrm{O}-\mathrm{P}$ (Figure $\mathrm{S} 1$ ). The phosphoric acid residue at C-28 of BDP is represented as a triplet at $\delta=+0.48 \mathrm{ppm}$, with a coupling 
constant $\mathrm{J}_{\mathrm{H}-\mathrm{P}} \sim 4.6 \mathrm{~Hz}$ that is characteristic of the $\mathrm{CH}_{2}$-O-P fragment of phosphatidic acids (alkylacyl glycerophosphates), where the signal $\left(\delta=+0.55 \mathrm{ppm}\right.$, the coupling constant $\mathrm{J}_{\mathrm{H}-\mathrm{P}} \sim 6.9 \mathrm{~Hz}$ ) corresponds to the $-\mathrm{CH}_{2}-\mathrm{O}-\mathrm{P}(\mathrm{O})(\mathrm{OH})_{2}$ fragment [29].

Phosphorus content determined by spectrophotometric analysis [30] was equal to $9.59-10.32 \%$ (Calc. content for $\mathrm{C}_{30} \mathrm{H}_{52} \mathrm{O}_{6} \mathrm{P}_{2}$ is equal to $10.30 \%$ ).

BDP assay was performed by reversed phase HPLC analysis: $210 \mathrm{~nm}, 40^{\circ} \mathrm{C}$, mobile phase $\mathrm{A} 30 \%-\mathrm{B} 70 \%$ $v / v$ (A-acetonitrile (grade 0), B-buffer solution of $\mathrm{KH}_{2} \mathrm{PO}_{4}, \mathrm{pH}=6.36$ ), flow $1.0 \mathrm{~mL} \cdot \mathrm{min}^{-1}$. The retention time is $5.19 \mathrm{~min}$.

BDP-1 and BDP-2 separation. The wet BDP crude (9 g) was dissolved in ethanol $(600 \mathrm{~mL})$ and the insoluble part (BDP-2) was filtered off. BDP-1 was isolated by precipitation from BDP ethanol solution with acetone, and BDP-1 was recrystallized from ethanol.

\subsubsection{Synthesis of the Sodium Salt of Betulin-3,28-diphosphate}

The sodium salt of betulin-3,28-diphosphate (Na-BDP) was obtained by adding $0.2-4.0 \mathrm{M}$ aqueous alkaline $\left(\mathrm{Na}_{2} \mathrm{CO}_{3}\right.$ or $\left.\mathrm{NaOH}\right)$ solutions to aqueous or ethanol BDP solutions. Na-BDP-1 and Na-BDP-2 were obtained from BDP- 1 and BDP-2, respectively. Na-BDP- 1 in the form of Na-BDP $8 \mathrm{H}_{2} \mathrm{O}$ crystalline hydrate (water content 16.80-17.27\%) was obtained by adding $4 \mathrm{M} \mathrm{NaOH}$ solution to alcohol solution of BDP-1. UV ( $\left.\mathrm{H}_{2} 0\right): \lambda_{\max }(\log \varepsilon) 256$ (2.62) nm; FTIR (KBr) $v_{\max } 3384,2330,1641-1700,1375,1089$, $975,513 \mathrm{~cm}^{-1}$; ${ }^{31} \mathrm{P}-\mathrm{NMR}\left(\mathrm{D}_{2} \mathrm{O}, 202.46 \mathrm{MHz}\right) \delta 4.25,4.31(\mathrm{~d}, J=8.4 \mathrm{~Hz}$, phosphoric acid residue at $\mathrm{C}-3 \beta), 5.47 \mathrm{ppm}$ ( $\mathrm{t}$, phosphoric acid residue at C-28). Sodium salt of BDP was obtained as $\mathrm{Na}_{2}-\mathrm{BDP}$ at $\mathrm{pH} 7$ and as $\mathrm{Na}_{4}-\mathrm{BDP}$ at $\mathrm{pH} 10$. Figure $\mathrm{S} 4$ shows the ${ }^{31} \mathrm{P}-\mathrm{NMR}$ spectrum of a $\mathrm{Na}_{4}-\mathrm{BDP}$ sample. Calculated phosphorus content for $\mathrm{C}_{30} \mathrm{H}_{48} \mathrm{O}_{8} \mathrm{P}_{2} \mathrm{Na}_{4}$ is equal to $9.09 \%$, while the phosphorus content found for $\mathrm{Na}_{4}$-BDP at $\mathrm{pH} 10$ was equal to $8.94 \%$ after drying. Calculated phosphorus content for $\mathrm{C}_{30} \mathrm{H}_{50} \mathrm{O}_{8} \mathrm{P}_{2} \mathrm{Na}_{2}$ is equal to $9.60 \%$, while the phosphorus content found for $\mathrm{Na}_{2}-\mathrm{BDP}$ at $\mathrm{pH} 7$ was equal to $9.54 \%$ after drying.

\subsection{Biological Activity In Vitro}

Biological activity in vitro was studied using blood stabilized with sodium citrate (1:9). Antioxidant properties were estimated with respect to the malonic dialdehyde (MDA) level in plasma and erythrocytes according to Uchiyama and Mihara technique [31] and superoxide dismutase (SOD, EC 1.15.1.1) activity. The energy metabolism in erythrocytes was studied using the catalytic activity of lactate dehydrogenase (LDH, EC 1.1.1.27) in the direct (substrate- $50 \mathrm{mM}$ sodium lactate) and reverse (substrate-23 mM sodium pyruvate) reaction [32,33].

The study as presented was approved by the Local Ethics Committee of Privolzhsky Research Medical University, Russian Federation (Protocol No.2 dated 20 February 2016).

\section{Conclusions}

Betulin-3,28-diphosphate samples obtained from betulin and $\mathrm{POCl}_{3}$ in dioxane in the presence of pyridine as $\mathrm{HCl}$ acceptor in molar ratio of betulin:POCl 3 :pyridine equal to $1: 6: 6$ at $0-2{ }^{\circ} \mathrm{C}$ during $24 \mathrm{~h}$ have two main structural forms, BDP-1 and BDP-2, which differ in ethanol solubility, melting point, FTIR spectra and thermoanalytical characteristics.

Readily water-soluble sodium salts of BDP obtained by adding alkaline $\left(\mathrm{NaOH}\right.$ or $\left.\mathrm{Na}_{2} \mathrm{CO}_{3}\right)$ solution to BDP solution differed too: Na-BDP-1 was obtained as needle-like crystals unlike poorly crystalline Na-BDP-2.

Thermoanalytical methods (DSC and TG) are convenient methods to study BDP structural forms. The exo-effects on the DSC curves at $193 \pm 8{ }^{\circ} \mathrm{C}$ can be used as the criteria to distinguish between BDP samples: $-19.7 \pm 0.2 \mathrm{~kJ} \cdot \mathrm{mol}^{-1}$ for BDP-1 and $-70.5 \pm 0.7 \mathrm{~kJ} \cdot \mathrm{mol}^{-1}$ for BDP-2 (sample reprecipitated by acetone). Another distinctive sign of BDP-1 is the presence of a first stage on the TG curve, which characterizes the loss of mass $\Delta \mathrm{m} / \mathrm{m}_{0}$ of $5-7 \%$, to $150{ }^{\circ} \mathrm{C}$, whereas for BDP-2 samples this stage is absent. The combination of BDP properties such as solubility, melting temperature, FTIR 
spectral characteristics, exo-effects on DSC curves and TG analysis data make it possible to definitely characterize type 1 (BDP-1) and type 2 (BDP-2). The endo-effects of Na-BDP on DSC curves are probably related to the removal of water from the structure of the initially formed hydrate.

The most probable reason for the transition of BDP-1 to BDP-2 are different topochemical processes, e.g., "structural reconstruction" leading to amorphous substances in accordance with powder XRD data.

Therefore, the use of BDP as a water-soluble potential active pharmaceutical ingredient is desirable in the form of $\mathrm{Na}-\mathrm{BDP} \times 8 \mathrm{H}_{2} \mathrm{O}$ crystal hydrate, that enables to ensure a satisfactory solubility of the preparation and, accordingly, its high biological activity estimated in vitro experiments on rats.

Supplementary Materials: The following are available online at http:/ /www.mdpi.com/1420-3049/23/5/1175/ s1, Figure S1: ${ }^{31} \mathrm{P}-\mathrm{NMR}$ spectrum of BDP $\left(\mathrm{DMSO}-\mathrm{d}_{6}\right.$, standard $\mathrm{Ph}_{3} \mathrm{P}$ in the presence of $\mathrm{H}_{3} \mathrm{PO}_{4}$ ), Figure S2: ${ }^{31} \mathrm{P}-\mathrm{NMR}$ spectra of BDP, DMSO-d 6 . a) BDP-1 sample, standard $\mathrm{Met}_{3} \mathrm{P}$; b) BDP-1 in the presence of $\mathrm{H}_{3} \mathrm{PO}_{4}$, standard $\mathrm{Ph}_{3} \mathrm{P}(\delta=-5.93 \mathrm{ppm})$ and $\left.\mathrm{H}_{3} \mathrm{PO}_{4}(\delta=-0.4 \mathrm{ppm}) ; \mathrm{c}\right)$ BDP-2 sample, standard Met ${ }_{3} \mathrm{P}$, Figure S3: ${ }^{1} \mathrm{H}-\mathrm{NMR}$ spectrum of BDP. DMSO-d $\mathrm{d}_{6}$, standard TMS, $400 \mathrm{MHz}$, Figure S4: ${ }^{31} \mathrm{P}-\mathrm{NMR}$ spectrum of Na-BDP. $\mathrm{D}_{2} \mathrm{O}$, standard $\mathrm{H}_{3} \mathrm{PO}_{4}$.

Author Contributions: N.B.M. conceived and designed the experiments, analyzed the data and wrote the paper; D.S.M., I.N.K., D.V.B., V.A.V., P.S.P., A.V.K. and A.V.M. performed the experiments.

Funding: This research received no external funding.

Conflicts of Interest: The authors declare no conflict of interest.

\section{References}

1. Falamas, A.; Pinzaru, S.C.; Chis, V.; Dehelean, C. Spectroscopic investigations of newly formed betulin-cyclodextrin quest-host type complexes as potential anti skin cancer candidates. J. Mol. Struct. 2011, 993, 297-301. [CrossRef]

2. Yogeeswari, P.; Sriram, D. Betulinic acid and its derivatives: A review on their biological properties. Curr. Med. Chem. 2005, 12, 657-666. [CrossRef] [PubMed]

3. Cichewicz, R.H.; Kouzi, S.A. Chemistry, biological activity, and chemotherapeutic potential of betulinic acid for the prevention and treatment of cancer and HIV infection. Med. Res. Rev. 2004, 24, 90-114. [CrossRef] [PubMed]

4. Barret, J.P.; Podmelle, F.; Lipový, B.; Rennekampff, H.O.; Schumann, H.; Schwieger-Briel, A.; Zahn, T.R.; Metelmann, H.R. Accelerated re-epithelialization of partial-thickness skin wounds by a topical betulin gel: Results of a randomized phase III clinical trials program. Burns 2017, 43, 1284-1294. [CrossRef] [PubMed]

5. Yu, H.; Dong, S.; Wang, L.; Liu, Y. The effect of triterpenoid saponins on pancreatic lipase in vitro: Activity, conformation, kinetics, thermodynamics and morphology. Biochem. Eng. J. 2017, 125, 1-9. [CrossRef]

6. Bureeva, S.; Andia-Pravdivy, J.; Symon, A.; Bichucher, A.; Moskaleva, V.; Popenko, V.; Shpak, A.; Shvets, V.; Kozlov, L.; Kaplun, A. Selective inhibition of the interaction of C1q with immunoglobulins and the classical pathway of complement activation by steroids and triterpenoids sulfates. Bioorg. Med. Chem. 2007, 15, 3489-3498. [CrossRef] [PubMed]

7. Chrobak, E.; Bebenek, E.; Kadela-Tomanek, M.; Latocha, M.; Jelsch, Ch.; Wenger, E.; Boryczka, S. Betulin phosphonates; Synthesis, structure, and cytotoxic activity. Molecules 2016, 21, 1123. [CrossRef] [PubMed]

8. Muhammad, A.; Carlson, R.M.; Karim, M.R.; Krasutsky, P.A. Inhibition of Epstein-Barr virus by the triterpenoid betulin diphosphate and uvaol. J. Microbiol. Biotechnol. 2004, 14, 1086-1088.

9. Pradere, U.; Garnier-Amblard, E.C.; Coats, S.J.; Amblard, F.; Schinazi, R.F. Synthesis of nucleoside phosphate and phosphonate prodrugs. Chem. Rev. 2014, 114, 9154-9218. [CrossRef] [PubMed]

10. Krasutsky, P.A.; Carlson, R.M.; Karim, M.R. Triterpenes having Antibacterial Activity. U.S. Patent US t6,689,767 B2, 10 February 2004.

11. Krasutsky, P.A.; Carlson, R.M.; Karim, M.R. Triterpenes having Human Antifungal and Antiyeast Activity. U.S. Patent US 6,642,217 B2, 4 November 2003.

12. Kaplun, A.P.; Andija-Pravdivyi, J.E.; Bureeva, S.V.; Kozlov, L.V.; Shvets, V.I. The Derivatives of Betulin as Inhibitors of the Complement System. Rus. Patent RU 2,243,233, 27 December 2004. 
13. Pfeffer-Hennig, S.; Piechon, P.; Bellus, M.; Goldbronn, C.; Tedesco, E. Physico-chemical characterization of an active pharmaceutical ingredient. Crystal polymorphism and structural analysis. J. Therm. Anal. Calorim. 2004, 77, 663-679. [CrossRef]

14. Veronez, I.P.; Daniel, J.S.P.; Garcia, J.S.; Trevisan, M.G. Characterization and compatibility study of desloratadine. J. Therm. Anal. Calorim. 2014, 115, 2407-2414. [CrossRef]

15. Almeida, M.M.; Bou-Chacra, N.A.; Lima, C.R.R.C.; Matos, J.R.; Filho, E.M.; Mercuri, L.P.; Baby, A.R.; Kaneko, T.M.; Velasco, M.V.R. Characterization and evaluation of free and nanostructured ursolic acid incorporated in cosmetic formulation using thermal analysis. J. Therm. Anal. Calorim. 2014, 115, 2401-2406. [CrossRef]

16. Aitipamula, S. Polymorphism in molecular crystals and cocrystals. In Advances in Organic Crystal Chemistry, 1st ed.; Tamura, R., Miyata, M., Eds.; Springer: Tokyo, Japan, 2015; pp. 265-298.

17. Wiedemann, H.G.; Felder-Casagranda, S. Thermomicroscopy. In Handbook of Thermal Analysis and Calorimetry, 1st ed.; Brown, M.E., Ed.; Elsevier Science B.V.: Amsterdam, The Netherlands, 1998; Volume 1, pp. $472-496$.

18. Perrenot, B.; Widmann, G. Polymorphism by differential scanning calorimetry. Thermochim. Acta 1994, 234, 31-39. [CrossRef]

19. Wang, X.; Gong, N.; Yang, S.; Du, G.; Lu, Y. Studies on solvatomorphism of betulinic acid. J. Pharm. Sci. 2014, 103, 2696-2703. [CrossRef] [PubMed]

20. Markin, A.V.; Markhasin, E.; Sologubov, S.S.; Ni, Q.Z.; Smirnova, N.N.; Griffin, R.G. Low-temperature polymorphic phase transition in a crystalline tripeptide l-Ala-l-Pro- $\mathrm{Gly} \cdot \mathrm{H}_{2} \mathrm{O}$ revealed by adiabatic calorimetry. J. Phys. Chem. B 2015, 119, 1787-1792. [CrossRef] [PubMed]

21. Wesolowski, M.; Rojek, B. Thermogravimetric detection of incompatibilities between atenolol and excipients using multivariate techniques. J. Therm. Anal. Calorim. 2013, 113, 169-177. [CrossRef]

22. Elks, J.; May, P.J.; Phillipps, G.H. 21-Phosphate Esters of $17 \alpha$-acyloxy-21 Hydroxy Steroids of the Pregnane Series. U.S. Patent No. US 3,764,616, 9 October 1973.

23. Symon, A.V.; Kaplun, A.P.; Vlasenkova, N.K.; Gerasimova, G.K.; Shon, L.B.; Litvin, E.F.; Kozlova, L.M.; Surkova, E.L.; Shvets, V.I. Epimerization of Hydroxyl Group in Lupan Series Triterpenoids. Rus. J. Bioorg. Chem. 2003, 29, 185-189. [CrossRef]

24. Son, L.B.; Kaplun, A.P.; Spilevskiı̆, A.A.; Andiia-Pravdivyı̆, I.E.; Alekseeva, S.G.; Gribor'ev, V.B.; Shvets, V.I. Synthesis of betulinic acid from betulin and study of its solubilization usingliposomes. Bioorganicheskaia Khimiia 1998, 24, 787-793. [PubMed]

25. Kuznetsova, S.A.; Skvortsova, G.P.; Maliar, I.N.; Skurydina, E.S.; Veselova, O.F. Extraction of betulin from birch bark and study of its physico-chemical and pharmacological properties. Russ. J. Bioorganic Chem. 2014, 40, 742-747. [CrossRef]

26. Shimkin, A. Optimization of DSC calibration procedure. Thermochim. Acta 2013, 566, 71-76. [CrossRef]

27. Höhne, G.W.H.; Hemminger, W.F.; Flammersheim, H.-J. Differential Scanning Calorimetry, 2nd ed.; Springer: New York, NY, USA, 2003.

28. Drebushchak, V.A. Calibration coefficient of heat-flow DSC. Part II: Optimal calibration procedure. J. Therm. Anal. Calorim. 2005, 79, 213-218. [CrossRef]

29. Khromova, N.Y.; Malekin, S.I.; Kisin, A.V.; Nosova, V.M.; Kruglyak, Y.L.; Kurochkin, V.K. Preparative synthesis of 1,2- and 1,3-disubstituted phosphatidic acids. Russ. J. Bioorg. Chem. 1999, 25, 268-272.

30. Mahadevaiah, M.S.; Yogendra, K.; Abdul Galil, M.S.; Suresha, M.S.; Sathish, M.A.; Nagendrappa, G. A simple spectrophotometric determination of phosphate in sugarcane juices, water and detergent samples. J. Chem. 2007, 4, 467-473. [CrossRef]

31. Mihara, M.; Uchiyama, M. Determination of malonaldehyde precursor in tissues by thiobarbituric acid test. Anal. Biochem. 1978, 86, 271-278. [PubMed]

32. Solovyeva, A.G.; Zimin, Y.V. A new estimation method of blood metabolism dynamics of patients with heat injuries. Mod. Technol. Med. 2012, 2, 116-117.

33. Waterborg, J.H.; Matthews, H.R. The Lowry method for protein quantitation. Methods Mol. Biol. 1994, 32, 1-4. [PubMed]

Sample Availability: Samples of the compounds are available from the authors. 
(C) 2018 by the authors. Licensee MDPI, Basel, Switzerland. This article is an open access article distributed under the terms and conditions of the Creative Commons Attribution (CC BY) license (http://creativecommons.org/licenses/by/4.0/). 